\title{
PENGUATAN SIKAP INTEGRITAS MELALUI PELATIHAN DASAR CALON PEGAWAI NEGERI SIPIL
}

\author{
Amat Budiman \\ Badan Pengembangan Sumber Daya Manusia \\ Provinsi Riau, Pekanbaru, Indonesia \\ amatbudi7070@gmail.com \\ Received: August $25^{\text {th }}, 2020$ \\ Revised: August $30^{\text {th }}, 2020$ \\ Accepted: August $31^{\text {st }}, 2020$
}

\section{ABSTRACT}

Civil Servants (PNS) are part of the State Civil Service (ASN). Before being sworn in to become part of the ASN, PNS had the status of Civil Servant Candidates (CPNS). CPNS are then required to take Basic Training (Latsar) in order to have an attitude of integrity at work. Integrity is a mess to ensure consistency in the work of civil servants so that the organization moves towards a positive work climate. This article aims to describe the importance of strengthening the integrity of the CPNS through basic training. This article uses a literature approach to describe a topic in a systematic manner. Integrity behavior shows how a person has consistency in moral principles that are used as a guide in making decisions. Integrity is able to provide learning regarding work dedication. Strengthening integrity can be done gradually. Thus, integrity is expected as a form of organizational management that moves groups of individuals to achieve organizational goals.

Keyword: CPNS; integrity; organization goals.

\section{PENDAHULUAN}

Calon Pegawai Negeri Sipil (CPNS) memerlukan pelatihan dasar (dikenal dengan Latsar) untuk kemudian menyandang status Pegawai Negeri Sipil. Pegawai Aparatur Sipil Negara selanjutnya disebut Aparatur Sipil Negara (ASN) merupakan pegawai pemerintahan Indonesia (Nadeak, 2017). ASN diangkat oleh Pejabat Pembina Kepegawaian dan diserahi tugas dalam suatu jabatan pemerintahan atau diserahi tugas negara lainnya dan digaji berdasarkan peraturan perundang-undangan (Pasal 1 ayat (2) Undang-Undang Republik Indonesia Nomor 5 Tahun 2014 tentang Aparatur Sipil Negara).Sebutan Pegawai Negeri Sipil dalam undang-undang ASN masih tetap dipakai. Pada UndangUndang Nomor 43 Tahun 1999 ada dua golongan Pegawai Negeri, yaitu Pegawai Negeri Sipil (PNS) dan Angkatan Bersenjata Indonesia (Hurry, 2020). Pegawai 
Negeri Sipil terdiri dari Pegawai Negeri Sipil Pusat, Pegawai Negeri Sipil Daerah dan Pegawai Negeri Sipil lain yang ditetapkan dengan Peraturan Permerintah.

Tercapainya tujuan tersebut ditentukan oleh kualitas dan kinerja Pegawai Negeri Sipil, dengan posisi yang demikian maka diperlukan manajemen Pegawai Negeri sipil yang mampu secara komprehensif dan terperinci menjelaskan posisi, peran, hak dan kewajiban para Pegawai Negeri Sipil tersebut. Namun pada kondisi pada saat ini terjadi fenomena dimana PNS kurang memiliki integritas, hal tersebut dapat dilihat dari penurunan kesadaran PNS untuk melakukan kewajiban seperti disiplin waktu dalam bekerja dan semangat kerja yang cenderung menurun, penurunan tersebut dapat disebabkan dari berbagai aspek dan tidak menutup kemungkinan aspek yang bersifat pemenuhan kebutuhan PNS tersebut. Untuk itu perlu stimulus bagi PNS dalam menimbulkan kembali semangat disiplin bekerja.

Dalam menjalankan tugas, terdapat kode etik dan kode perilaku bagi Pegawai Negeri Sipil yang harus dipedomani. Kode etik dan kode perilaku itu berisi pengaturan perilaku agar Pegawai ASN (PNS) melaksanakan tugasnya dengan jujur, betanggung jawab, dan berintegritas tinggi. Intergritas PNS sudah diatur dan harus dihormati oleh PNS. Keseluruhan peraturan tersebut dipaparkan dalam Latsar CPNS. Perihal ini bukan tanpa alasan, melainkan untuk membangun integritas antar CPNS sebelum disumpah. Krisis integritas merupakan permasalahan klasik dalam organisasi. Integritas menyeruak sebagai nilai yang harus dimiliki oleh setiap orang calon pegawai negeri sipil.

Dalam konteks kepemimpinan integritas menimbulkan kepercayaan dan keselarasan dalam bekerja. Namun, dalam konteks pengikut (yang dipimpin) integritas mampu merekatkan koordinasi dan menjunjung erat dedikasi kerja. Artikel ini bertujuan untuk mendeskripsikan pentingnya membangun integritas dalam kerangka latihan dasar calon dasar pegawai negeri sipil. Oleh karena itu, diharapkan muncul pemahaman yang holistik berkenaan kewajiban dan hak antar unsur organisas guna mencapai tujuan bersama. 


\section{METODE PENELITIAN}

Studi pustaka merupakan kajian teoritis berdasarkan referensi, buku, jurnal yang berhubungan mendeskripsikan membangun integritas persfektif budaya melalui pelatihan dasar (Latsar) calon pegawai negeri sipil pada Badang Pengembangan Sumber Daya Manusia Provinsi Riau. Tinjauan literatur menggunakan buku dan jurnal. Artikel bersifat deskriptif dengan menggunakan narasi secara terstruktur (Rahmanto, 2004). Namun, di samping studi kepustakaam, artikel ini menggunakan pendekatan empiris penulis. Dengan demikian diharapkan gagasan bersifat rasional yang dibentuk oleh individu melalui pengalaman (Sarman, 2004).

\section{HASIL DAN PEMBAHASAN}

Integritas merupakan sebuah standar moralitas dan etika seseorang, tidak ada hubungannya dengan situasi yang kebetulan ada di sekitar Anda dan tidak mendorong kecepatan. Konsep integritas itu sendiri di dalamnya mengidentikkan dengan kata hati, akuntabilitas moral, komitmen moral, dan konsistensi moral seseorang antara perilaku yang ditunjukkannya dan nilai-nilai atau prinsip-prinsip tertentu (Soegiharto, 2014).

Konsep integritas pada Executive Brain Assessment diklasifikasikan menjadi tiga dimensi yaitu: kejujuran, konsistensi, dan keberanian. Integritas dimaknai sebagai bentuk kecakapan dan kejujuran yang diimplementasikan dalam kehidupan sehari-hari (Prawani SR, 2013). Nilai integritas sangat penting diterapkan dalam organisasi. Hal ini dimaksudkan agar memunculkan saling kepercayaan antar subjek di dalam organisasi. Di samping itu, integritas membantu mencapai tujuan organisasi cepat. Manakala nilai-nilai integritas tidak dijalankan, maka kerjasama tim yang dilakukan akan menjadi lebih sulit akibat tidak terbangunnya kepercayaan yang komprehensif di antara mereka.

Nilai integritas tidak hanya melekat kepada sosok pemimpin, melainkan seluruh komponen dalam organisasi. Integritas dalam persfektif budaya mempengaruhi terhadap sikap ketegasan dan keselarasannya atas pikiran dan perkataan. Adapun kaitannya dengan Pegawai Negeri Sipil integritas berkenaan 
dengan pembangunan karakter (Huslina \& Islahuddin, 2015). Namun hal ini seringkali terkendala dikarenakan perbedaan latar budaya. Dengan demikian diperlukan pembangunan integritas dalam persfektif budaya melalui pembinaan karakter dalam kerangka Latihan Dasar (Latsar) Calon Pegawai Negeri Sipil (CPNS).

Integritas merupakan komitmen dan kepatuhan terhadap negara. Dalam membangun kekuatan bangsa dengan segenap pranata, prinsip dan kondisi yang diyakini kebenarannya serta digunakan sebagai instrumen pengatur kehidupan moral, identitas, karakter serta jatidiri bangsa yang berdasarkan Pancasila dan UUD Negara RI 1945. Pancasila dan UUD Negara RI 1945 merupakan modal dasar yang mampu mendinamisasikan pembangunan nasional di segala bidang. Kesiapsiagaan bela negara merupakan aktualisasi nilai-nilai bela negara dalam kehidupan bermasyarakat, berbangsa dan bernegara sesuai peran dan profesi warga negara, demi menjaga kedaulatan negara, keutuhan wilayah dan keselamatan segenap bangsa dari segala bentuk ancaman yang pada hakikatnya mendasari konsep nation dan character building (Dwiningwarni, 2017).

Konsep nation dan character building menjadi fokus untuk untuk mencapai integritas Latihan Dasar (Latsar) Calon Pegawai Negeri Sipil (CPNS). Harapan yang dimaksudkan adalah memiliki semangat cinta tanah air, kesadaran berbangsa dan bernegara, yakin Pancasila sebagai idiologi negara, kerelaan berkorban demi bangsa dan Negara. Kesiapsiagaan Bela Negara merupakan kondisi Warga Negara yang secara fisik memiliki kondisi kesehatan, keterampilan dan jasmani yang prima serta secara kondisi psikis yang memiliki kecerdasan intelektual, dan spiritual yang baik. Hal ini senantiasa memelihara jiwa dan raganya memiliki sifat-sifat disiplin, ulet, kerja keras dan tahan uji, merupakan sikap mental dan perilaku warga negara yang dijiwai oleh kecintaan kepada NKRI.

Nilai integritas bagi CPNS merupakan kesiapsiagaan yang terintegrasi guna menghadapi situasi kontijensi dan eskalasi ancaman sebagai dampak dari dinamika perkembangan lingkungan strategis yang juga mempengaruhi kondisi dalam negeri yang dipicu oleh faktor ideologi, politik, ekonomi, sosial budaya, pertahanan dan keamanan. Undang-Undang Nomor 5 Tahun 2014 tentang 
Aparatur Sipil Negara mengamanatkan Instansi Pemerintah Untuk wajib memberikan Pendidikan dan Pelatihan terintegrasi bagi Calon Pegawai Negeri Sipil (CPNS) selama satu tahun masa percobaan (Hurry, 2020). Tujuan dari Pelatihan terintegrasi ini adalah untuk membangun integritas moral, kejujuran, semangat dan motivasi nasionalisme dan kebangsaan, karakter kepribadian yang unggul dan bertanggungjawab, dan memperkuat profesionalisme serta kompetensi bidang. Dengan demikian UU ASN mengedepankan penguatan nilainilai dan pembangunan karakter dalam mencetak PNS (Hanum \& Arribathi, 2019).

Secara substansial konsep integritas tertuang dalam dokumen pakta berdasarkan ketentuan Pasal 1 angka 1 Permen PANRB 49/2011, diterangkan bahwa dokumen pakta integritas adalah dokumen yang berisi pernyataan atau janji kepada diri sendiri tentang komitmen melaksanakan seluruh tugas, fungsi, tanggung jawab, wewenang dan peran sesuai dengan peraturan perundangundangan dan kesanggupan untuk tidak melakukan korupsi, kolusi dan nepotisme (Fathya, 2018)

Lingkungan strategis berkembang sangat dinamis, penuh ketidakpastian dan kompleks, sehingga sangat sulit bagi suatu negara untuk mengetahui potensi dan hakikat ancaman serta tantangan terhadap kepentingan nasional. Pentingnya membangun integritas memposisikan peran integritas memegang peran penting dalam menentukan keberhasilan dalam berbagai hal (Ashari, 2010). Maka sebagai Pegawai Negeri Sipil (PNS), tidak bisa lengah mengimplementasikan integritas, melalui sumpah dan janji yang tertuang dalam naskah sumpah yang pernah diucap ketika dilantik sebagai PNS maupun dalam pengukuhan sumpah jabatan. Secara sederhana integritas bagi PNS tersebut dapat dimaknai:

Pertama, integritas sebagai sebuah komitmen dan loyalitas. Komitmen adalah janji pada diri sendiri maupun orang lain yang tercermin dalam tindakan, sikap dan perilaku seseorang. Sedangkan loyalitas merupakan pelaksanaan komitmen sesuai ketentuan yang berlaku. Seseorang yang loyal patuh terhadap ketentuan yang mengatur sikap, perilaku dan perbuatannya. Komitmen menuntut seseorang menepati janji walaupun dalam keadaan sulit. Faktor pemicu 
kegagalan dalam melaksanakan komitmen antara lain; keyakinan yang goyah, gaya hidup yang salah, pengaruh lingkungan dan keliru memaknai loyalitas.

Kedua, integritas sebagai sebuah tanggungjawab. Tanggungjawab identik dengan kedewasaan bertindak. Seseorang yang bertanggungjawab tentu akan bersedia menghadapi resiko, memperbaiki keadaan dan melaksanakan kewajiban dengan kemampuan terbaiknya. Sebaliknya bukan perilaku melarikan diri dari tanggungjawab akan merasa sedang terlepas dari sebuah beban, padahal justru sebaliknya akan menambah beban baru bagi dirinya. Artinya semakin seseorang lari dari tanggungjawab, maka dia akan semakin kehilangan tujuan dan makna hidup, bahkan banyak yang akhirnya jadi pecundang.

Ketiga, integritas sebagai kualitas dan disiplin diri. Kualitas hidup seseorang ditentukan oleh sejumlah daya dukung seperti pengetahuan, keterampilan, wawasan, kejujuran, kesetiaan dan sebagainya. Sedangkan disiplin diri berarti melakukan sesuatu yang seharusnya dilakukan melalui pengendalian diri dan sikap hidup yang teratur serta seimbang. Disiplin diri dapat membentuk kualitas hidup seseorang. Sikap disiplin tidak identik dengan kerja keras tanpa istirahat.

Keempat, integritas sebagai sebuah konsistensi. Seseorang dapat dikatakan konsisten apabila tetap pada pendiriannya. Ketegasan pada keputusan dan pendirian yang tidak tergoyahkan tersebut bukan berarti sikap keras dan kaku. Namun lebih ditekankan pada sikap untuk melakukan sesuatu secara benar dan tidak ragu berdasarkan fakta yang akurat, tujuan yang jelas dan pertimbangan yang bijak.

Keempat makna di atas memberikan penegasan bahwa integritas membantu kita untuk menguasai diri dan berdisiplin diri. Banyak orang keliru menggambarkan sikap disiplin sehingga menyamakan disiplin dengan bekerja keras tanpa istirahat. Padahal sikap disiplin berarti melakukan yang seharusnya dilakukan, bukan sekedar hal yang ingin dilakukan. Disiplin mencerminkan sikap pengendalian diri, suatu sikap hidup yang teratur dan seimbang serta berorientasi pada tugas yang diberikan kepadanya. Nilai integritas mengandung nilai yang meliputi kejujuran, kemandirian, kedisiplinan, tanggung jawab, kerja keras, sederhana, keberanian, dan keikhlasan. Salah satu dari nilai itu yang sangat bersinggungan dengan 
tulisan adalah keikhlasan. Keikhlasan di sini adalah ketulusan dan kejujuran dari seorang Pegawai Negeri Sipil untuk menerima atau mendapatkan apa yang sudah menjadi hak dan menjalankan kewajiban.

\section{KESIMPULAN}

Implementasi sikap integritas merupakan kepastian bagi Pegawai Negeri Sipil (PNS). Dalam bentuk perilaku integritas terlihat bagaimana seseorang memiliki konsistensi prinsip moral yang digunakan sebagai pegangan dalam membuat keputusan. Di samping itu, integritas memberikan pembelajaran berkenaan dedikasi kerja. Oleh karena itu, penalaran etis perihal integritas dapat dilakukan melalui pelatihan dasar (Latsar) Calon Pegawai Negeri Sipil (CPNS). Hal ini dikarenakan pembangunan integritas dilakukan dengan bertahap. Dengan demikian, diharapkan integritas sebagai upaya menjaga organisasi yang menggerakkan kumpulan individu mencapai tujuan organisasi.

\section{DAFTAR PUSTAKA}

Ashari, E. T. (2010). Memahami Karakteristik Pegawai Negeri Sipil yang Profesional. Civil Service Journal, 4 (2 November).

Dwiningwarni, S. S. (2017). Pengaruh Budaya Organisasi Dengan Pendekatan Integritas, Etos Dan Lingkungan Kerja Terhadap Kinerja Organisasi. Eksis: Jurnal Riset Ekonomi dan Bisnis, 12 (2), , 149-160.

Fathya, V. N. (2018). Upaya Reformasi Birokrasi melalui Area Perubahan Mental Aparatur untuk Memberantas Praktik Pungutan Liar yang dilakukan oleh PNS. CosmoGov: Jurnal IImu Pemerintahan, 4 (1), 38-57.

Hanum, G. K., \& Arribathi, H. A. (2019). Hubungan Antara Integritas (Kejujuran Dan Konsistensi) Dengan Kepercayaan Studi Korelasional Pada Guru SMP Negeri Kecamatan Cipayung Jakarta Timur. Journal Educational Of Nursing (Jen), 2(1), 147-152.

Hurry, S. D. (2020). Pencegahan Korupsi Melalui Pembangunan Kompetensi Sosio Kultural (Integritas) PNS. Jurnal Legislasi Indonesia, 17 (1), 11-24.

Huslina, H., \& Islahuddin, N. S. (2015). Pengaruh Integritas Aparatur, Kompetensi Aparatur, dan Pemanfaatan Teknologi Informasi Terhadap Efektivitas Sistem Pencegahan Fraud. Jurnal Administrasi Akuntansi: Program Pascasarjana Unsyiah, 4 (1). 
Nadeak, B. (2017). Pengaruh Locus Of Control, Integritas, Dan Komunkasi Interpersonal Terhadap Kepuasan Kerja Pns Dinas Pendidikan, Pemuda, Dan Olahraga Kabupaten Karawang Tpengaruh Locus Of Control, Integritas, Dan Komunkasi Interpersonal Terhadap Kepuasan Kerja Pns Dinas . Jurnal Politikom Indonesiana, 2 (2).

Prawani SR, D. (2013). Memahami Sebuah Konsep Integritas. Jurnal Stie Semarang (Edisi Elektronik), 5 (3), , 1-14.

Rahmanto, B. (2004). Metode Pengajaran Sastra. Yogyakarta: Kanisius.

Sarman, M. (2004). Pengantar Metodologi Penelitian Sosial. Banjarmasin. Kalsel: Pustaka FISIP UNLAM.

Soegiharto, R. (2014). Membangun Integritas Widyaiswara. Jurnal Lingkar Widyaiswara, 1 (4), 92-103. 